\title{
Evaluation of the antioxidant and hepatoprotective properties of the methanolic extract of Acalypha racemosa leaf in carbon tetrachloride-treated rats
}

\author{
Iniaghe, O. M. ${ }^{1 \star}$, Malomo, S. O. ${ }^{2}$, Adebayo, J. O. ${ }^{2}$, and Arise, R. O. ${ }^{2}$ \\ ${ }^{1}$ Department of Biochemistry, Faculty of Natural Sciences, Ambrose Alli University, Ekpoma, Nigeria. \\ ${ }^{2}$ Department of Biochemistry, University of Ilorin, Ilorin, Nigeria. \\ Accepted 9 May, 2008
}

\begin{abstract}
The effects of simultaneous treatment of $\mathrm{CCl}_{4}$ with 60 and $120 \mathrm{mg} / \mathrm{kg}$ body weight of methanolic extract of Acalypha racemosa on rat liver were evaluated. Analysis of serum alanine aminotransferase (ALT) and aspartate aminotransferase (AST) activities with those of the concentrations of albumin, total protein, unconjugated and total bilirubin was carried out. The malondialdehyde (MDA) content of liver was determined to investigate a probable mechanism of action of the extract. Histopathological studies were carried out to confirm the observed changes. Administration of $\mathrm{CCl}_{4}$ alone to rats significantly increased total bilirubin concentration and the activities of ALT and AST $(p<0.05)$ in the serum while it significantly reduced $(p<0.05)$ serum total protein and albumin concentrations when compared with controls. Also, it significantly increased $(p<0.05)$ liver MDA content when compared to control. However, simultaneous administration of $\mathrm{CCl}_{4}$ with 60 and $120 \mathrm{mg} / \mathrm{kg}$ of the methanolic extract significantly $(p<0.05)$ reversed these changes. Since both doses of the methanolic extract of $A$. racemosa were able to significantly reduce liver MDA content, it thus suggests that a probable mechanism of action of the extract is antioxidation.
\end{abstract}

Key words: Acalypha racemosa, hepatoprotective property, antioxidant effect.

\section{INTRODUCTION}

Reactive oxygen species (ROS) have been implicated in more than 100 diseases (Ali et al., 2001). Experimental, clinical, and epidemiological studies have provided evidence in support of the role of ROS in the etiology of cancer (Ray et al, 2000). When produced in excess, ROS cause tissue injury. All aerobic organisms including humans have antioxidant defense mechanisms that protect against oxidative damage. However, the natural antioxidant defense mechanisms can be insufficient and hence dietary intake of antioxidant components is important and recommended (Duh, 1998).

A number of plants have been shown to possess hepatoprotective properties by improving the antioxidant status e.g. Caesalpinia bonducella (Gupta et al, 2005). However, there is still lack of scientific proofs to authenticate the hepatoprotective properties of some plants

\footnotetext{
${ }^{\star}$ Corresponding author. E-mail: iniaghe@yahoo.com. Tel: +234 8036484014.
}

which are used traditionally to treat liver disorders. An example of such is Acalypha racemosa (Euphorbiaceae). $A$. racemosa is considered as an indigenous source of medicine exhibiting antibacterial activity (Musa et al., 2000). Also, traditional healing practitioners in llorin metropolis, Nigeria, use the decoction of $A$. racemosa leaves to treat liver disorders and other disease conditions which result in jaundice.

In our previous work, some of the secondary plant metabolites detected in the aqueous and methanolic extracts of the leaves of $A$. racemosa are flavonoids and phenolics (Iniaghe et al., 2008). Since it has been demonstrated that phenolic compounds are effective antioxidants, due to formation of stable phenoxyl radical (Burton et al., 1981), and that flavonoids have potent antioxidant activities by scavenging hydroxyl radicals, superoxide anions and lipid peroxy radicals (Alan and Miller, 1996), it is reasonable to evaluate the antioxidant property of the leaves of this plant.

Thus, this present investigation was undertaken to evaluate the hepatoprotective activities of methanolic ex- 
tract of the leaves of A.racemosa against oxidative damage induced by $\mathrm{CCl}_{4}$ in rats and to evaluate the possibility of extracts enhancing bilirubin clearance from the serum when its level is elevated.

\section{MATERIALS AND METHODS}

\section{Animals}

The twenty albino rats (Rattus novergicus) used for this study were obtained from the Animal holding unit of the Department of Biochemistry, University of Ilorin, Ilorin, Nigeria. They were maintained in standard conditions of temperature, relative humidity and light/night cycles. They were allowed free access to commercial pelleted rat chow (Bendel Feeds Ltd, Ewu, Nigeria) and water ad libitum.

\section{Chemicals}

2,4-Dinitrophennylhydrazine and bromocresol green were obtained from Randox Company, United Kingdom. All other reagents used were of analytical grade and were prepared in all glass distilled water.

\section{Plant material and extraction}

The leaves of $A$. racemosa were obtained from Mount Olives Anglican Church, Pipeline Road, Tanke, Ilorin, Kwara State, Nigeria and were identified at the Herbarium section of the Department of Plant Biology of the University of llorin. Fifty grams of shade-dried leaves pulverized to powder was percolated in $500 \mathrm{mls}$ of methanol. The mixture was allowed to stand for $24 \mathrm{~h}$ and then filtered to obtain the methanolic extract. The filtrate was evaporated to dryness in a water bath at $60^{\circ} \mathrm{C}$.

\section{Experimental design}

The rats were randomly divided into four groups $(n=5)$ as follows: (i) Control received orally $1 \mathrm{ml}$ of distilled water daily.(ii) Group A received $1.5 \mathrm{ml} / \mathrm{kg}$ body weight (i.p.) $\mathrm{CCl}_{4}$ daily. (iii) Group B received $1.5 \mathrm{ml} / \mathrm{kg}$ body weight (i.p.) $\mathrm{CCl}_{4}$ and $60 \mathrm{mg} / \mathrm{kg}$ body weight of methanolic extract of $A$. racemosa leaves (orally) simultaneously. (iv) Group C received $1.5 \mathrm{ml} / \mathrm{kg}$ (i.p.) $\mathrm{CCl}_{4}$ and $120 \mathrm{mg} / \mathrm{kg}$ body weight of methanolic extract of A.racemosa leaves (orally) simultaneously.

After the experimental period of seven days, animals were sacrificed and venous blood was collected into sample bottles containing no anticoagulant as earlier reported (Adebayo et al., 2003). The blood samples were allowed to clot and the serum was obtained by centrifuging at $3000 \mathrm{rpm}$ for $5 \mathrm{~min}$ (Ogbu and Okechukwu, 2001). The clear serum was removed by pipetting which was used for the assay of aspartate aminotransferase (AST) and alanine aminotransferase (ALT) activities and the determination of concentrations of serum total protein, albumin, unconjugated bilirubin and total biliburin.

A section of the liver for each rat in each group was preserved in $10 \%$ formalin for histopathological studies while the remaining was homogenized in ice-cold $0.25 \mathrm{M}$ sucrose solution $(1: 5, \mathrm{w} / \mathrm{v})$ and centrifuged at $4000 \mathrm{rpm}$ for $10 \mathrm{~min}$. The supernatant was used for the estimation of malondialdehhyde (MDA) content and liver total protein concentration.

\section{Biochemical studies}

The determination of serum albumin concentration was done using the method described by Gowenlock et al. (1998) while that of serum bilirubin concentration was done using the method described by Malloy and Evelyn (1937). Liver malondialdehyde content determination was done by measuring the concentration of thiobarbituric acid reacting substrate (TBARS) in liver using the method of Olusin (2002). Total protein concentration was estimated in the serum and liver using the Biuret method (Plummer, 1978). The activities of serum aminotransferases (ALT and AST) were assayed basically by the method of Reitman and Frankel (1957). The method of Baker and Silverton (1985) was employed for the histopathological studies.

\section{Statistical analysis}

The statistical analysis was carried out by one way Analysis of variance and Duncan Multiple Range test. $\mathrm{P}$ values $<0.05$ were considered significant.

\section{RESULTS}

Histopathological studies of the liver of control animals showed normal histology (Figure 1a). Animal groups to which $\mathrm{CCl}_{4}$ was simultaneously administered with 60 and $120 \mathrm{mg} / \mathrm{kg}$ body weight of methanolic extract of $A$. racemosa leaves separately also showed normal liver histology (Figures $1 \mathrm{c}$ and 1d, respectively). For animals to which $\mathrm{CCl}_{4}$ only was administered, inflammation of hepatic cells was observed (Figure $1 \mathrm{~b}$ ).

Administration of $\mathrm{CCl}_{4}$ alone to rats caused a significant increase $(p<0.05)$ in serum unconjugated bilirubin and serum total biliirubin (Table 1) when compared with controls. Simultaneous administration of each extract dose with $\mathrm{CCl}_{4}$ to rats significantly reduced $(\mathrm{p}<0.05)$ the level of unconjugated biliirubin in serum to the range of the control value.

Simultaneous administration of $120 \mathrm{mg} / \mathrm{kg}$ body weight of methanolic extract with $\mathrm{CCl}_{4}$ significantly reduced the level of serum total biliirubin $(P<0.05)$ when compared with $\mathrm{CCl}_{4}$ treated group while simultaneous treatment of $\mathrm{CCl}_{4}$ with $60 \mathrm{mg} / \mathrm{kg}$ body weight of methanolic extract showed no significant difference $(p>0.05)$ when compared with $\mathrm{CCl}_{4}$ treated group (Table 1).

A significant decrease $(p<0.05)$ in concentration of albumin in serum of rats treated with $\mathrm{CCl}_{4}$ only and those treated with $\mathrm{CCl}_{4}+60 \mathrm{mg} / \mathrm{kg}$ body weight of methanolic extract when compared with control was observed (Table 2). The change effected by the administration of $\mathrm{CCl}_{4}$ only was significantly reversed $(p<0.05)$ by the simultaneous administration of $\mathrm{CCl}_{4}$ with $120 \mathrm{mg} / \mathrm{kg}$ body weight of methanolic extract.

Treatment of rats with $\mathrm{CCl}_{4}$ alone significantly reduced $(p<0.05)$ the concentration of total protein in both the liver and the serum when compared with control (Table 2). Similar effects were observed in groups which received $\mathrm{CCl}_{4}$ simultaneously with $60 \mathrm{mg} / \mathrm{kg}$ body weight of methanolic extract. Simultaneous administration of rats with 
Table 1. Effects of methanolic extract of $A$. racemosa leaves on serum bilirubin levels in experimental rats.

\begin{tabular}{|l|c|c|}
\hline Group & $\begin{array}{c}\text { Serum unconjugated bilirubin } \\
\text { concentration }(\boldsymbol{\mu m o l} / \mathbf{L})\end{array}$ & $\begin{array}{c}\text { Serum total bilirubin } \\
\text { concentration }(\boldsymbol{\mu m o l} / \mathbf{L})\end{array}$ \\
\hline Control: Distilled water only & $4.50 \pm 0.13^{\mathrm{a}}$ & $7.40 \pm 0.24^{\mathrm{a}}$ \\
$\mathrm{CCl}_{4}(1.5 \mathrm{ml} / \mathrm{kg}$ ) only & $8.50 \pm 0.25^{\mathrm{b}}$ & $8.10 \pm 0.25^{\mathrm{b}}$ \\
$\mathrm{CCl}_{4}+60 \mathrm{mg} / \mathrm{kg}$ methanolic extract & $5.60 \pm 0.20^{\mathrm{a}}$ & $8.10 \pm 0.32^{\mathrm{b}}$ \\
$\mathrm{CCl}_{4}+120 \mathrm{mg} / \mathrm{kg}$ methanolic extract & $5.80 \pm 0.30^{\mathrm{a}}$ & $7.20 \pm 0.67^{\mathrm{a}}$ \\
\hline
\end{tabular}

Values are mean \pm S.D of 5 determinations. Values with different alphabet superscripts are significantly different at $\mathrm{P}<0.05$.

Table 2. Effects of methanolic extract of $A$. racemosa leaves on serum and liver protein levels in experimental rats.

\begin{tabular}{|l|c|c|c|}
\hline Group & $\begin{array}{c}\text { Serum albumin } \\
\text { concentration }(\mathbf{g} / \mathbf{L})\end{array}$ & $\begin{array}{c}\text { Serum total protein } \\
\text { concentration (g/L) }\end{array}$ & $\begin{array}{c}\text { Liver total protein } \\
\text { concentration (mg/ml) }\end{array}$ \\
\hline Control: Distilled water only & $26.0 \pm 1.0^{\mathrm{a}}$ & $46.0 \pm 3.0^{\mathrm{a}}$ & $4.57 \pm 0.16^{\mathrm{a}}$ \\
$\mathrm{CCl}_{4}(1.5 \mathrm{ml} / \mathrm{kg})$ only & $18.5 \pm 0.9^{\mathrm{b}}$ & $34.0 \pm 3.2^{\mathrm{b}}$ & $3.65 \pm 0.11^{\mathrm{b}}$ \\
$\mathrm{CCl}_{4}+60 \mathrm{mg} / \mathrm{kg}$ methanolic extract & $19.0 \pm 0.3^{\mathrm{b}}$ & $36.0 \pm 3.0^{\mathrm{b}}$ & $3.73 \pm 0.16^{\mathrm{b}}$ \\
$\mathrm{CCl}_{4}+120 \mathrm{mg} / \mathrm{kg}$ methanolic extract & $23.0 \pm 1.0^{\mathrm{c}}$ & $45.0 \pm 2.3^{\mathrm{a}}$ & $4.97 \pm 0.22^{\mathrm{a}}$ \\
\hline
\end{tabular}

Values are mean \pm S.D of 5 determinations. Values with different alphabet superscripts are significantly different at $\mathrm{P}<0.05$.

(a)

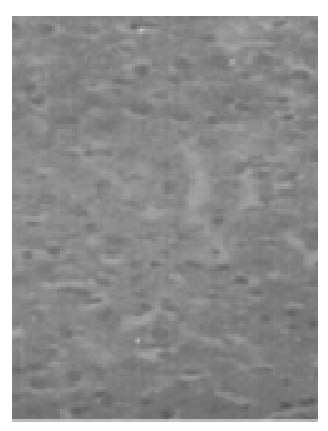

(c)

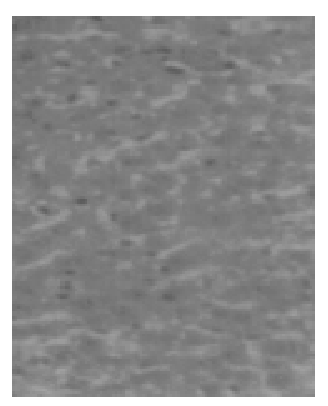

(b)

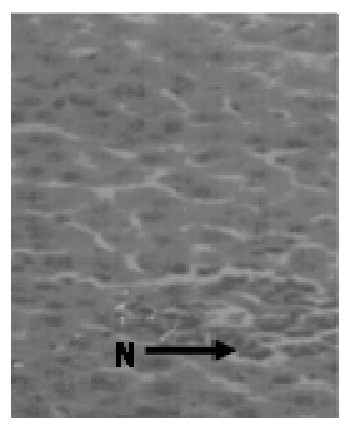

(d)

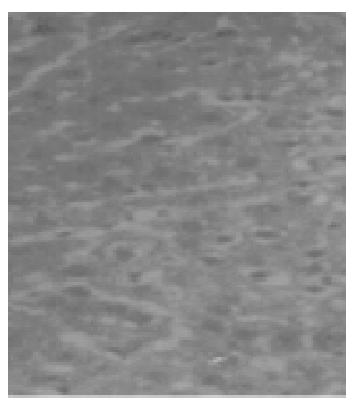

Figure 1. Photomicrographs of the liver of experimental rats (Magnification: $\mathrm{x} 400) . \mathrm{N}=$ neutrophils at the site of inflammation. a: Control (rats received distilled water only). b: Rats received $\mathrm{CCl}_{4}$ $(1.5 \mathrm{ml} / \mathrm{kg})$ only. c: Rats received $\mathrm{CCl}_{4}+60 \mathrm{mg} / \mathrm{kg}$ methanolic extract of $A$. racemosa leaves. d: Rats received $\mathrm{CCl}_{4}+120 \mathrm{mg} / \mathrm{kg}$ methanolic extract of $A$. racemosa leaves.

$\mathrm{CCl}_{4}$ with $120 \mathrm{mg} / \mathrm{kg}$ body weight of methanolic extract significantly reversed the change $(p<0.05)$.

A significant increase $(p<0.05)$ in MDA content, an end product of lipid peroxidation, in the liver of rats treated with $\mathrm{CCl}_{4}$ only was observed when compared with control (Table 3). Simultaneous administration of $\mathrm{CCl}_{4}$ with each of the two extract doses significantly reduced $(p<0.05)$ the MDA content in the liver when compared with that of rats administered $\mathrm{CCl}_{4}$ only, thus restoring it back to the range of control (Table 3 ).

Table 3 also shows the effect of the methanolic extract of A.racemosa leaves on the activities of serum AST and ALT in rats. Hepatotoxicity was evidenced by a significant increase $(p<0.05)$ in the activities of serum AST and ALT in the group treated with only $\mathrm{CCl}_{4}$ when compared with control. Simultaneous administration of the extract at both doses with $\mathrm{CCl}_{4}$ significantly reduced $(\mathrm{p}<0.05)$ the activities of these enzymes in serum when compared with the group treated with $\mathrm{CCl}_{4}$ only.

\section{DISCUSSION}

The effects of the methanolic extracts of $A$. racemosa leaves on carbon tetrachloride - induced hepatotoxicity in albino rats were evaluated. For animals to which $\mathrm{CCl}_{4}$ only was administered, inflammation (signified by the appearance of neutrophils) and an early phase of necrosis of hepatic cells were observed (Figure 1b). Neutrophils 
Table 3. Effects of methanolic extract of $A$. racemosa leaves on liver MDA content and serum AST and ALT activities in experimental rats.

\begin{tabular}{|l|c|c|c|}
\hline Group & $\begin{array}{c}\text { Liver MDA content } \\
(\mu \mathrm{mol} / \mathbf{L})\end{array}$ & $\begin{array}{c}\text { Serum AST activity } \\
(\mathbf{U} / \mathbf{L})\end{array}$ & $\begin{array}{c}\text { Serum ALT activity } \\
(\mathbf{U} / \mathbf{L})\end{array}$ \\
\hline Control: Distilled water only & $45.00 \pm 10.50^{\mathrm{a}}$ & $36.5 \pm 0.05^{\mathrm{a}}$ & $27.1 \pm 0.06^{\mathrm{a}}$ \\
$\mathrm{CCl}_{4}(1.5 \mathrm{ml} / \mathrm{kg})$ only & $80.00 \pm 4.00^{\mathrm{b}}$ & $90.0 \pm 0.10^{\mathrm{b}}$ & $89.4 \pm 0.01^{\mathrm{b}}$ \\
$\mathrm{CCl}_{4}+60 \mathrm{mg} / \mathrm{kg}$ methanolic extract & $55.00 \pm 7.00^{\mathrm{a}}$ & $87.1 \pm 0.05^{\mathrm{c}}$ & $77.6 \pm 0.09^{\mathrm{c}}$ \\
$\mathrm{CCl}_{4}+120 \mathrm{mg} / \mathrm{kg}$ methanolic extract & $54.00 \pm 4.00^{\mathrm{a}}$ & $53.5 \pm 0.20^{\mathrm{d}}$ & $47.6 \pm 0.01^{\mathrm{d}}$ \\
\hline
\end{tabular}

Values are mean \pm S.D of 5 determinations. Values with different alphabet superscripts are significantly different at $P<0.05$.

are characteristic of inflammation in the early stages. They are the first to appear in an infected area (Guyton and Hall, 2000). An attempt has been made to explain the mechanism leading to the infiltration of inflammatory cells into liver and liver cell necrosis resulting from $\mathrm{CCl}_{4}$ poisoning. After $\mathrm{CCl}_{4}$ poisoning, intracellular adhesion molecule 1 (ICAM 1) in the liver tissue increases (especially in sinusoidal endothelial cells and hepatocytes) (Neubauer, 1998). Also leukocyte function antigen 1 (LFA-1) around vessel wall increases, thus leukocyte function antigen 1 and ICAM 1 accumulate at necrotic areas increasing inflammatory cells and inducing hepatotoxicity (Neubauer, 1998). No inflammation was observed in those rats to which $\mathrm{CCl}_{4}$ and methanolic extract of $A$. racemosa leaves were simultaneously administered (Figures 1c and 1d). It is, therefore, suggests that the seven-day administration of the methanolic extract of $A$. racemosa leaves at both doses was effective in reversing the hepatotoxicity caused by the administration of $\mathrm{CCl}_{4}$. Bilirubin is the main bile pigment that is formed from the breakdown of heme in the red blood cells. It is transported to the liver where it is secreted by the liver into the bile. Conjugation of bilirubin is a prerequisite for its excretion into the bile (Nelson and Cox, 2000). Malfunctioning of the liver was evidenced by the significant increase $(p<0.05)$ in the level of unconjugated bilirubin in the serum of the group treated with only $\mathrm{CCl}_{4}$ when compared with control (Table 1). Increase in the level of unconjugated bilirubin in the blood may result from a defect in the function of the liver to conjugate the bilirubin being produced (Marks and Dennis, 1996). The significant reduction $(p<0.05)$ of unconjugated bilirubin level in the serum when $\mathrm{CCl}_{4}$ was simultaneously administered with each of the doses of the methanolic extract when compared with the administration of $\mathrm{CCl}_{4}$ alone indicates that the conjugating function of the liver was improved. The reduction of the unconjugated bilirubin level by the extracts suggests that the extracts may activate the constitutive androstane receptor (CAR) which is a key regulator in bilirubin clearance in the liver (Moore et al., 2004). The primary function of CAR in the bilirubin clearance pathway is to direct a coordinate response to elevated levels of bilirubin by increasing the hepatic expression of each component of the pathway (Moore et al., 2004).
The ability of simultaneous administration of $\mathrm{CCl}_{4}$ with $120 \mathrm{mg} / \mathrm{kg}$ body weight methanolic extract to significantly reduce $(p<0.05)$ the level of serum total bilirubin when compared with that of the $\mathrm{CCl}_{4}$ - treated group suggests the potential of the extract in clearing bilirubin from the serum when its level is elevated (Table 1) (Gupta et al., 2005). On the other hand, the inability of $60 \mathrm{mg} / \mathrm{kg}$ body weight methanolic extract to reverse the increase in serum total bilirubin level brought about by $\mathrm{CCl}_{4}$ suggests the limited restoration of the activity of the liver in secreting conjugated bilirubin into the bile probably by reason of containing lower concentrations of the bioactive agents.

Due to the fact that the results obtained for the serum albumin, serum total protein and liver protein concentrations followed the same trend (Table 2), it thus implicates the same mechanism by which the extract exerts its effect on these three parameters. The administration of $\mathrm{CCl}_{4}$ alone may adversely interfere with protein metabolism probably by inhibiting the synthesis of proteins such as albumin in the liver. Simultaneous administration of $\mathrm{CCl}_{4}$ to rats with $120 \mathrm{mg} / \mathrm{kg}$ body weight methanolic extract significantly $(p<0.05)$ reversed these changes, maybe by increasing protein synthesis. This indicates the hepatoprotective activity of $A$. racemosa leaves against damage by $\mathrm{CCl}_{4}$. Stimulation of protein synthesis has been advanced as a contributory hepatoprotective mechanism which accelerates regeneration of cells (Awang, 1993).

Hepatotoxicity was also evidenced by a significant increase $(p<0.05)$ in activities of serum AST and ALT in the group treated with only $\mathrm{CCl}_{4}$ when compared with controls (Table 3 ). This may result from leakage from the cells through peroxidative damage of the membrane. This is evidenced by the increase in liver MDA content after the administration of $\mathrm{CCl}_{4}$ only (Table 3). MDA level is used to determine early liver oxidative stress (Tokyay et al., 1999). It is also used to investigate the oxidative damage of proteins and lipid peroxidation of the membrane and lipoproteins as possible pathogenic mechanism for liver injury (Kocic et al., 1998). The hepatotoxic effects of the metabolism of $\mathrm{CCl}_{4}$ are due to its active metabolite, trichloromethyl radical (Johnson and Bhutani, 1998). The activated radical binds covalently to the macro-molecules and induce peroxidative degradation of 
membrane lipids of endoplasmic reticulum which are rich in polyunsaturated fatty acids. This leads to the formation of lipid peroxides which in turn gives product such as malondialdehyde (MDA) that causes damage to the membranes. This lipid peroxidative degradation of biomolecules is one principal cause of hepatotoxicity of $\mathrm{CCl}_{4}$ (Cotran et al., 1994). The increased liver MDA contents in rats treated with $\mathrm{CCl}_{4}$ only suggest that the natural antioxidant defense mechanism to scavenge excessive free radicals has been compromised. Increased serum bilirubin level in this group could be looked upon as a compensatory/retaliatory phenomenon in response to cellular peroxidative changes (Pratibha et al., 2004). This is because bilirubin functions in vivo as a powerful antioxidant, anti-mutagen, and an endogenous tissue protector (Pratibha et al., 2004). Thus, there is a positive correlation between MDA content and serum bilirubin level which supports the report of Pratibha et al. (2004).

However, simultaneous administration of each dose of the methanolic extract with $\mathrm{CCl}_{4}$ significantly reduced $(p<0.05)$ the activities of these enzymes in the serum when compared with the group treated with $\mathrm{CCl}_{4}$ only. Results indicate that the administration of $120 \mathrm{mg} / \mathrm{kg}$ body weight methanolic extract with $\mathrm{CCl}_{4}$ was most effective. This also indicates hepatoprotection.

These findings all point to the fact that the methanolic extract of $A$. racemosa leaves is hepatoprotective against $\mathrm{CCl}_{4}$ induced liver damage. Hence it is possible that a probable mechanism of hepatoprotection of $A$. racemosa leaf extract against $\mathrm{CCl}_{4}$ induced damage is the antioxidant activity. The antioxidant activity of the extracts may be attributed to the presence of phenolics and flavonoids (Iniaghe et al., 2008).

\section{REFERENCES}

Adebayo JO, Yakubu MT, Egwin EC, Owoyele BV, Enaibe BU (2003). Effect of Ethanolic extract of Khaya Senegalensis on some Biochemical Parameters of Rat Kidney. J. Ethnopharmacol. 88: 6972.

Alan L, Miller ND (1996). Antioxidant flavonoids: Structure, function and clinical usage. Alt. Med. Rev. 1(2): 103-111.

Ali Y, Munir O, Vahit B (2001). The antioxidant activity of leaves of Cydonia vulgaris. Turk. J. Med. Sci. 31: 23-27.

Awang D (1993). Milk Thistle. Can. Pharm. J. 23: 749-754.

Baker FJ, Silverton RE (1985). Introduction to Medical Laboratory Technology. 6th Edition. Butterworths. London, pp. 171-235

Cotran RS, Kumar V, Robbins SL (1994). Cell injury and cellular diseases. $5^{\text {th }}$ edition. Prism Book. Pub. Ltd. pp. 379-430.

Duh PD (1998). Antioxidant activity of Burdock, its scavenging effect on free radical and active oxygen. J. Am. Oil. Chem. Soc. 75: 455-458.

Gupta M, Mazumder UK, Kumar RS, Sivakumar T, Gomathi P, Rajeshwar Y (2005). Antioxidant defense system induced by a mwethanol extract of Caesapinia bonducella in rat liver. Pharmaceut. Biol. 43(5): 411-419.
Guyton AC, Hall JE (2000). A textbook of Medical Physiology. $10^{\text {th }}$ Edition. Saunders WB, Company Philadelphia. pp. 382-401.

Iniaghe OM, Malomo SO, Adebayo JO, Arise RO (2008). Proximate composition, phytochemical constituents and antibacterial properties of leaves of some acalypha species. Pak. J. Nutr. (In Press).

Johnson LH, Bhutani VK (2002). System based approach to management of neonatal jaundice and prevention of kernicterus. J. Pediatric. 140: 396-403.

Kocic G, Viahovic P, Pavlovic D, Kocic R, Cvetkovict T, Stojanovic I (1998). The possible importance of the cation binding site for the oxidative modification of liver 5-nucleotidase. Arch. Physiol. Biochem. 106(2): 91-99.

Malloy E, Evelyn K (1937). The determination of bilirubin with photoelectric colorimeter. J. Biol. Chem. 119: 481-485.

Marks MD, Dennis L (1996). Jaundice. www.medicinenet.com.

Moore D, Jun Z, Werdong H (2004). Induction of bilirubin clearance by xenobiotic receptor CAR. J. Clin. Invest. 113: 137-143.

Musa KY, Ibrahim HM, Arowosiaye G, Olanitola OS (2000). Phytochemical and antimicrobial studies of leaves of Acalypha racemosa. Niger. J. Nat. Prod. Med. 4: 67-69.

Nelson DC, Cox MM (2000). Lehninger Principles of Biochemistry. $3^{\text {rd }}$ edition. Worth Publishers, USA, p. 842.

Neubauer K (1998). Carbon tetrachloride induced liver injury. Lab. Invest. 78(2): 185-194.

Ogbu SI, Okechukwu EI (2001). The effect of storage temperature prior to separation on plasma and serum potassium. J. Med. Lab. Sci. 10: 1-4.

Olusin SO (2002). Obesity is an essential independent risk factor for plasma lipid peroxidation and deplection of erythrocyte cytoprotenic enzyme in human. Int. J. Obes. 26: 1159-1164.

Plummer DT (1978). An introduction to practical Biochemistry. $2^{\text {nd }}$ edition. McGraw- Hill, London, pp. 144-145.

Pratibha K, Usha A, Rajni A (2004). Serum adenosine deaminase $5^{1}$ nucleotidase and malondialdehyde in acute infective hepatitis. Indian J. Clin. Biochem. 19(2): 128-131.

Ray G, Batra S, Shkula NK, Deo S, Raina V, Asok S, Husain SA (2000). Lipid peroxidation, free radicals production, and antioxidant status in breast cancer. Breast Cancer Res. Treat. 59: 163-170.

Reitman S, Frankel S (1957). Determination of aspertate aminotransferase. Am. J. Clin. Pathol. 2: 856.

Tokyay R, Kaya E, Gur ES, Tuncel P, Ozbek R, Oztuk E (1999). Prostaglandin Synthetase inhibition reduces peritonitis induced early liver oxidant stress. Surg. Today. 29(1): 42-46. 